\title{
The Effects of Topiramate Therapy on Cerebral Metabolism in Migraine with Aura Patients
}

\author{
Auraln Migren Hastalarnda Topiramat Tedavisinin Serebral \\ Metabolizma Üzerine Etkileri
}

\author{
Omer KARADAS ${ }^{1}$, Hakan Levent GUL ${ }^{2}$, Bilgin OZTURK³ ${ }^{3}$ Erdal EROGLU³ ${ }^{3}$, Seref DEMIRKAYA ${ }^{3}$ \\ ${ }^{1}$ Erzincan Military Hospital, Neurology Service, Erzincan, Turkey \\ ${ }^{2}$ Kartal Education and Research Hospital, Department of Neurology, Istanbul, Turkey \\ ${ }^{3}$ Gulhane Military Medical Academy, Department of Neurology, Ankara, Turkey \\ Presented as a poster at the 15th Congress of the International Headache Society, June 23-26, 2011, Berlin, Germany.
}

Corresponding Author: Hakan Levent GUL / E-mail: leventgul2003@yahoo.com

\begin{abstract}
AIM: Topiramate is an antiepileptic drug with multiple mechanisms of action that is also used for migraine prophylaxis. This study aimed to investigate the efficacy of topiramate therapy for migraine prophylaxis, based on vasomotor reactivity ([VMR] an indicator of cerebral autoregulation), and to identify changes in cerebral hemodynamics during the treatment.

MATERIAL and METHODS: We included 20 migraine (with aura) patients (group 1) and 20 healthy controls (group 2) in the study. Transcranial Doppler monitoring was performed in both groups with patients in the supine and resting position. Using a two-sided temporal window at depths of 45-60 mm for the middle cerebral artery (MCA) and depths of 60-70 mm for the posterior cerebral artery (PCA), basal flow rates and VMR values were measured. Group 1 initially received $25 \mathrm{mg} / \mathrm{d}$ of topiramate orally, and then the dose was increased $25 \mathrm{mg}$ every week. At the fourth week; the optimal dose was increased to $50 \mathrm{mg}$ b.i.d. and the treatment was continued at this dose. Transcranial Doppler parameters were re-evaluated 2 months after treatment. In addition, the number of attacks per month, duration of pain, and visual analog scale (VAS) scores obtained before the treatment and 2 months after the treatment in group 1 were compared.

RESULTS: Basal flow rates and VMR values recorded from the right and left MCA in group 1 were significantly higher than those in the control group $(P<0.05)$. Flow velocities obtained from the right and left MCA, and the VMR values in group 1 after topiramate treatment did not differ significantly from those in the control group $(P>0.05)$. In addition, the number of attacks, duration of pain, and VAS scores in group 1 were significantly lower after the treatment than before the treatment $(P<0.05)$.
\end{abstract}

CONCLUSION: Topiramate is an effective prophylactic treatment in migraine with aura patients and appeared to play a positive role in the regulation of cerebrovascular autonomic control.

KEYWORDS: Migraine, Topiramate, Cerebral vasomotor reactivity, Preventive treatment, Transcranial doppler

öz

AMAÇ: Çalışmada, serebral otoregülasyonun bir göstergesi olan vazomotor reaktivite (VMR)'nin, migren proflaksisinde topiramat tedavisine yanıtları ve topiramat tedavisi sırasında serebral hemodinamideki değişikliklerin incelenmesi amaçlanmıştır.

YÖNTEM VE GEREÇLER: Çalışmaya, 20 migren hastası (Grup 1) ve 20 sağlıklı kontrol deneği (Grup 2) alındı. Her iki grupta transkraniyal Doppler (TCD) yapıldı. Migrenli hastalara topiramat başlandı. Tedavi sonrası 2. ayda TCD parametreleri tekrar değerlendirildi.

BULGULAR: Topiramat tedavisi öncesi migren grubunda OSA bazal akım hızları ile VMR değerleri istatistiksel olarak anlamlı derecede $(p<0,05)$ yüksek bulundu. Migren grubunda topiramat tedavi sonrası saptanan, sağ ve sol OSA'dan elde edilen bazal akım hızları ile VMR değerleri, kontrol grubu ile karşılaştıııldığında farklııık saptanmadı ( $p>0,05)$.

SONUÇ: Migrenli hastaların proflaktik tedavisinde, topiramatın iyi bir seçenek olduğu ve serebrovasküler otonomik kontrolün regülasyonunda rol oynadığı söylenebilir.

ANAHTAR SÖZCÜKLER: Migren, Topiramat, Serebral vazomotor reaktivite, Önleyici tedavi, Transkraniyal doppler

ABBREVIATIONS: MCA: middle cerebral artery, CCA: common carotid artery, ICA: internal carotid artery, SAH: subarachnoid hemorrhage, BAC: balloon-assisted coiling, CVR: cortical venous reflux, DAVF: dural arteriovenous fistula, ECA: external carotid artery, MMA: middle meningeal artery, OA: occipital artery, TDAVF: tentorial DAVF, CS: cavernous sinus, CV: cortical vein, IPS: inferior petrosal sinus, SPS: superior petrosal sinu SSS: superior sagittal sinus, SOV: superior ophthalmic vein, PAA: posterior auricular artery, AMA: accessory meningeal artery, PMA: posterior meningeal artery, SR: sinus ractus, TS-SS: transverse sinus and sigmoid sinus. 


\section{INTRODUCTION}

Migraine is a common chronic neurovascular disease. Migraine headaches can present with aural neurological symptoms and autonomic nervous system dysfunction (11). Migraine attacks are characterized by numerous changes, including psychological and neurological, and structural or autonomic manifestations. Among patients with migraine, $15 \%$ have aura and the presence of 2 attacks of migraine starting with aura leads to the diagnosis. The aural phase, which is usually less than 1 hour in duration, includes positive or negative focal neurological symptoms that lead to or accompany the headache. The most frequent auras are visual, although sensory and motor auras can also be observed. Headaches usually occur within 1 hour after the aura, but can occur later or also may not occur (5).

Transcranial Doppler ultrasonography (TCD) is a safe and sensitive method for measuring cerebral blood flow velocity (CBFV) in the basal cerebral arteries. TCD can be used to evaluate the flow characteristics of intracranial arteries, microemboli, and vasomotor reactivity (VMR). The acoustic window is the cranial bone's thinnest region for using TCD and the transtemporal window facilitates insonation of the ipsilateral middle cerebral artery (MCA), anterior cerebral artery (ACA), and posterior cerebral artery (PCA) $(13,15,30,31)$. Neuronal activity is correlated with changes in local cerebral blood flow. As TCD can instantly show hemodynamic changes, it is a great tool for investigating the connection known as vasoneuronal coupling $(1,24)$.

Cerebral VMR is the capacity to meet the cerebral circulation and blood flow velocity (decrease and increase) based on cerebral metabolic changes. VMR is important for the autonomic and hemodynamic functioning of the cerebrum $(7,8,19,27,29)$ and we think that it can be helpful in following up the efficacy of migraine prophylaxis. Topiramate (TPM) is an antiepileptic with broad-spectrum and multiple mechanisms of action, and is used as a prophylactic treatment for migraine $(17,21)$. The present study aimed to evaluate the efficacy of TPM treatment on the frequency and duration of migraine attacks, visual analog scale (VAS) score, VMR (from both the right and left MCA, and P(A), and cerebral blood flow in migraine with aura patients.

\section{MATERIAL and METHODS}

This study was conducted under permission of institutional review board of "Dr. Lutfi Kirdar Kartal Education and Research Hospital, Istanbul, Turkey" (Decision \#: 1, 25.12.2012).

We included 20 ( 15 females, 5 males with a mean age of 32.75 years) migraine with aura patients (group 1) and 20 (16 females, 4 males with a mean age of 32.90 years) headachefree control subjects (group 2) in our study. All of the patients fulfilled the diagnostic criteria of migraine established by the Headache Classification Committee of the International Headache Society. The patients and controls provided informed consent to participate in the study. All patients had normal neurological examination findings.

\section{Exclusion Criteria}

Patients who had used any kind of prophylactic treatment for headache in the last 3 months, patients who had medication overuse headache according to The International Classification of Headache Disorders (2nd Edition), patients who had received botulinum toxin type A (BoNT-A) therapy, pregnant women or those with a positive urine pregnancy test, patients with a history of malignancy, patients who had a history of cervical and cranial surgery, patients who had ingested more than $500 \mathrm{mg} /$ day caffeine during last month, patients who had received non-pharmacological therapy for the last 6 months, patients with anemia or bleeding diathesis, patients with major psychiatric disorders (major depression etc.), patients who had used antipsychotic, antidepressant and antiepileptic drugs within the previous 3 months, patients with neuromuscular dysfunction, patients using agents that affect neuromuscular functions such as curare or antibiotics like aminoglycoside, patients with uncontrolled hypertension, patients with hypothyroidism or hyperthyroidism, and patients who had a history of primary headaches other than migraine with aura were not included in the study.

Whole blood count, routine biochemical tests, thyroid function tests, and vitamin B12, folic acid, and ferritin level measurements were performed to rule out secondary causes. Computerized Cranial Tomography (CCT) or Magnetic Resonance Imaging (MRI) were used as necessary.

\section{Study Design}

20 migraine patients underwent cerebral VMR measurement using TCD imaging of both MCAs and PCAs before and after TPM treatment. 20 controls also underwent VMR measurement with the same technique and by using the same arteries. Recordings were made with the participants in a comfortable supine position, using a DWL Multi-Dop T TCD Doppler instrument. Two 2-MHz pulse-wave probes were affixed to the transtemporal window. Doppler signals from the MCAs were obtained by placing the probe over the temple and adjusting the position for a maximal reflected signal at a depth of $45-60 \mathrm{~mm}$. Additionally, signals from the PCAs were recorded posteriorly and slightly caudally from the MCAs at a depth of $65-70 \mathrm{~mm}$. Breathholding was used to measure VMR in 3 sets. Patients and controls held their breath for 30 seconds and the procedure was continued after 5 minutes of rest.

Cerebral VMR was evaluated according to the breathholding index (BHI). $\mathrm{BHI}$ is calculated as follows: mean flow velocity at the end of breathholding - mean flow velocity at rest/mean flow velocity at rest $x$ 100/s of breathholding. Group 1 initially received $25 \mathrm{mg} /$ day of topiramate orally, and then the dose was increased by $25 \mathrm{mg}$ every week. At the fourth week the dose was increased to $50 \mathrm{mg}$ b.i.d. and this dose was continued; transcranial Doppler parameters were re-evaluated 2 months after the treatment. In addition, the number of attacks per month, duration of pain, and visual analog scale (VAS) scores in group 1 obtained before the treatment and 2 months after the treatment were compared. 


\section{Statistical Analysis}

SPSS v.15.0 was used for statistical analysis. Data are presented as mean \pm standard deviation. The Mann-Whitney $\mathrm{U}$ and Wilcoxon tests were employed, and a $\mathrm{P}$ value $<0.05$ was considered statistically significant.

\section{RESULTS}

20 (15 females, 5 males with a mean age of 32.75 years) migraine with aura patients (group 1) that received TPM and 20 (16 females, 4 males with a mean age of 32.90 years) healthy headache-free controls (group 2) were included in the study. There were no significant differences between the groups according to age and gender $(p>0.05)$.

The number of attacks in group 1 was $6.35 \pm 1.98$ before treatment and $4.05 \pm 1.57$ after treatment and this decrease was statistically significant $(p=0,01)$. Group 1's number of painful days was $12.55 \pm 5.09$ before treatment and $7.85 \pm 3.31$ after treatment and this decrease was statistically significant $(p<0,001)$. Group 1's VAS scores that show the severity of pain was $86.75 \pm 7.82$ before treatment and $59.75 \pm 18.38$ after treatment and this decrease was statistically significant $(\mathrm{p}<0.001)$.

The basal flow velocity values obtained from the right and left MCA and PCA before TPM treatment were significantly higher

Table I: Participant Demographic Features

\begin{tabular}{|c|c|c|c|}
\hline Variables & Group 1 & Group 2 & P \\
\hline Age (years) & $32.75 \pm 11.25$ & $32.90 \pm 11.98$ & 1.000 \\
\hline Gender & & & 0.982 \\
\hline Female & $15(75 \%)$ & $16(80 \%)$ & \\
\hline Male & $5(25 \%)$ & $4(20 \%)$ & \\
\hline
\end{tabular}

in group 1 than in the control group $(p<0.05)$. VMR values obtained from the right and left MCA and PCA before TPM treatment were again significantly higher in group 1 than in the control group $(p<0.05)$. The basal flow velocity recorded from the right and left MCA's, and the VMR values after TPM treatment in group 1 did not differ significantly from those in group $2(p>0.05)$.

The number of attacks, duration of pain, and VAS scores in group 1 were significantly lower after the treatment than before the treatment $(p<0.05)$. The number of attacks, duration of pain, and VAS scores were not recorded in group 2 as these subjects were headache free. The characteristics of the study population, mean flow velocities, and VMR values are shown in Tables I-III.

\section{DISCUSSION}

Prior to TPM treatment in group 1, basal cerebral blood flow velocity obtained bilaterally from the MCAs and PCAs, and VMR were significantly higher than those in the control group ( $p<0.05$ ), whereas 2 months after treatment, there were no significant differences in these parameters between the 2 groups ( $p>0.05$ ). Additionally, the number of attacks, duration of pain, and VAS scores after treatment in group 1 were significantly lower than the pre-treatment values $(p<$ 0.05). The present findings show that topiramate treatment was effective in migraine with aura patients, and regulated cerebral blood flow velocity and VMR.

Lauritzen reported that blood pressure autoregulation during migraine attacks is normal in all brain regions, but metabolic autoregulation (CO2 reactivity) is impaired in hypoperfused regions, as compared to normally perfused brain regions, after cortical spreading depression (CSD) (18). Nedeltchev et al. reported that migraine patients suffer from an autoregulation disorder, based on flow response behaviour in both MCAs and

Table II: Right and Left MCA and PCA Blood Flow Velocity

\begin{tabular}{|c|c|c|c|c|}
\hline & Group 1 & & Group 2 & Group 1 vs. Group 2 \\
\hline Blood flow velocity $\left(\mathrm{cm} \mathrm{s}^{-1}\right)$ & Median \pm SD & $\mathbf{p}$ & Median \pm SD & $\mathbf{p}$ \\
\hline \multicolumn{5}{|l|}{ Right MCA } \\
\hline $\begin{array}{l}\text { Before treatment } \\
\text { After treatment }\end{array}$ & $\begin{array}{l}60.77 \pm 5.48 \\
56.27 \pm 3.54\end{array}$ & $<0.001$ & $55.89 \pm 4.65^{*}$ & $\begin{array}{l}0.005 \\
0.579\end{array}$ \\
\hline \multicolumn{5}{|l|}{ Left MCA } \\
\hline $\begin{array}{l}\text { Before treatment } \\
\text { After treatment }\end{array}$ & $\begin{array}{l}61.32 \pm 3.58 \\
57.56 \pm 2.91\end{array}$ & $<0.001$ & $56.94 \pm 4.73^{*}$ & $\begin{array}{l}0.004 \\
0.534\end{array}$ \\
\hline \multicolumn{5}{|l|}{ Right PCA } \\
\hline $\begin{array}{l}\text { Before treatment } \\
\text { After treatment }\end{array}$ & $\begin{array}{l}42.56 \pm 2.55 \\
41.18 \pm 1.74\end{array}$ & 0.035 & $40.99 \pm 1.60^{*}$ & $\begin{array}{l}0.006 \\
0.839\end{array}$ \\
\hline \multicolumn{5}{|l|}{ Left PCA } \\
\hline $\begin{array}{l}\text { Before treatment } \\
\text { After treatment }\end{array}$ & $\begin{array}{l}44.22 \pm 1.33 \\
43.19 \pm 1.83\end{array}$ & 0.036 & $42.28 \pm 2.01^{*}$ & $\begin{array}{l}0.002 \\
0.130\end{array}$ \\
\hline
\end{tabular}

*One measurement was made in group 2. 
Table III: Right and left MCA and PCA VMR

\begin{tabular}{|c|c|c|c|c|}
\hline & \multicolumn{2}{|c|}{ Group 1} & \multirow{2}{*}{$\frac{\text { Group } 2}{\text { Median } \pm \text { SD }}$} & \multirow{2}{*}{$\frac{\text { Group } 1 \text { vs. Group } 2}{\text { p }}$} \\
\hline VMR & Median \pm SD & $\mathbf{p}$ & & \\
\hline Right MCA & & & & \\
\hline $\begin{array}{l}\text { Before treatment } \\
\text { After treatment }\end{array}$ & $\begin{array}{l}1.49 \pm 0.18 \\
1.38 \pm 0.10\end{array}$ & $<0.001$ & $1.36 \pm 0.11^{*}$ & $\begin{array}{l}0.015 \\
0.766\end{array}$ \\
\hline Left MCA & & & & \\
\hline $\begin{array}{l}\text { Before treatment } \\
\text { After treatment }\end{array}$ & $\begin{array}{l}1.53 \pm 0.10 \\
1.41 \pm 0.10\end{array}$ & $<0.001$ & $1.38 \pm 0.12^{*}$ & $\begin{array}{l}0.001 \\
0.387\end{array}$ \\
\hline Right PCA & & & & \\
\hline $\begin{array}{l}\text { Before treatment } \\
\text { After treatment }\end{array}$ & $\begin{array}{l}1.54 \pm 0.15 \\
1.47 \pm 0.11\end{array}$ & 0.014 & $1.41 \pm 0.13^{*}$ & $\begin{array}{l}0.012 \\
0.076\end{array}$ \\
\hline Left PCA & & & & \\
\hline $\begin{array}{l}\text { Before treatment } \\
\text { After treatment }\end{array}$ & $\begin{array}{l}1.50 \pm 0.11 \\
1.46 \pm 0.11\end{array}$ & 0.040 & $1.42 \pm 0.08^{*}$ & $\begin{array}{l}0.010 \\
0.156\end{array}$ \\
\hline
\end{tabular}

*One measurement was made in group 2.

PCAs (using visual stimuli during an attack-free period) (20). Ayata et al. evaluated the efficacy of prophylactic migraine drugs on CSD using a rat model. Valproate, propranolol, amitriptyline, TPM, and methysergide were administered. They reported that chronic use of these drugs reduced the frequency of CSD (dose dependently) by $40 \%-80 \%$ (6).

It remains unclear via what mechanism TPM acts as a migraine preventive (14). Storer and Goadsby reported that TPM inhibits neurons of the trigeminocervical complex following superior sagittal sinus stimulation (25). Shank reported the molecular activity of TPM, as follows: inhibits voltage-gated $\mathrm{Na}$ and $\mathrm{Ca}$ channels; modulates glutamate-mediated neurotransmission (reducing depolarization induced by AMPA and kainatemediated currents); enhances some types of GABA receptors; inhibits carbonic anhydrase; modulates $\mathrm{K}$ conductance and proteins that regulate neurotransmitter release from synaptic terminals (22). TPM acts by reducing nociceptive transmission via trigeminovascular modulation and inhibition of CSD $(2,25)$. Ackerman and Goadsby showed that TPM was also able to inhibit NO-induced dural blood vessel dilation (3). They reported that TPM attenuates the NO response, presumably inhibiting the release of CGRP from trigeminal neurons, but not the NO-cGMP interaction that produces dilation of blood vessels. It seems unlikely that TPM acts directly on dural blood vessels, as it is unable to inhibit CGRP-induced dilation (3).

Thie et al. examined 100 patients (common or classic migraine) using TCD and compared the patients to a control group (40 young controls). They reported that all intracranial arteries in the migraine patients had higher average flow rates, and that the vascular reactivity in the PCAs in response to eye closing was significantly higher in the migraine group than in the control group (26). Fiermonte et al. studied 3 groups (control [ $n=15]$, migraine with aura [ $n=15]$, and migraine without aura $[n=15]$ ) and reported that cerebrovascular CO2 reactivity was higher during the interictal period in the migraine with aura patients (13). Recently, Valikovics et al. measured baseline blood flow velocity in the MCAs of 51 migraine patients and 101 controls; cerebrovascular reactivity was measured after intravenous administration of acetazolamide in 12 migraneous patients and in 19 controls. Baseline mean velocity was significantly higher in the migraine group and the difference remained significant during acetazolamide stimulation, but the course of response did not differ between the controls and migraine patients (30).

Vernieri et al. observed higher blood flow velocity in the MCAs and VMR in 16 migraine patients than in 21 controls. Their findings provide additional evidence of an abnormality in cerebral autoregulatory mechanisms in migraine patients (31). Dora and Balkan studied patients with migraine and a control group. They reported that $\mathrm{BHI}$ was significantly higher in the patients, and that elevated reactivity might be associated with an increase in vascular tonus; however, normal blood flow velocity and high reactive responses were observed in the patients. These findings suggest that the reactive responses in the migraine patients were due to altered hypersensitivity to $\mathrm{CO} 2$ (9). Dora and Balkan also studied 20 migraine patients and 11 healthy controls, comparing $\mathrm{BHI}$ before and after $10 \mathrm{mg}$ flunarizine per day treatment. Before treatment $\mathrm{BHI}$ values were significantly higher in the migraine group, whereas after 3 months of treatment the difference in $\mathrm{BHI}$ was no longer significant (10). Fiermonte et al. reported higher cerebral blood flow velocity in migraine patients with and without aura, and higher VMR in the migraine with aura patients. Following 2 months of flunarizine treatment, VMR in the migraine with aura patients was within normal limits, whereas blood flow rates did not change. Flunarizine reduced VMR without affecting the cerebral blood flow velocity, which indicated that its mechanism of action is not related to vasodilatation (12). 
Kastrup et al. studied 20 migraine patients and 30 controls using TCD of both MCAs and PCAs, and reported that mean cerebrovascular blood flow velocity and $\mathrm{CO} 2$ reactivity were higher in the patients with migraine (15). The same year Kastrup et al. investigated metoprolol treatment and reported that it had no effect on reactivity in migraine patients that had elevated reactivity before treatment (16). Silvestrini et al. evaluated cerebrovascular reactivity in the MCAs and basilar arteries in 15 migraine patients with aura, 15 migraine patients without aura, and 15 healthy controls. VMR obtained from the MCAs was similar in all groups, but VMR obtained from the basilar arteries were lower in the patients with migraine and aura (23).

In conclusion, the literature clearly shows that there is a relationship between migraine and cerebral hemodynamics, especially MCA hemodynamics; however, unlike other studies, the present study used TPM as a prophylactic treatment, the $\mathrm{BH}$ procedure was employed, and both right and left MCA and PCA hemodynamics were simultaneously evaluated. Based on the present study's findings, TPM was efficacious in migraine with aura patients and TPM played a role in the regulation of cerebral hemodynamics.

The limitations of our study is that the number of patients included was relatively small and that it would be better to compare the control group with migraine patients who have not received TPM treatment. Further work is needed to show the relationships between migraine and hemodynamic abnormalities, treatment options, and their effects on cerebral blood flow. Our VMR results and VAS scores showed that TPM is an effective drug for prevention of migraine and reducing the severity of attacks.

\section{REFERENCES}

1. Aaslid R, Lindegaard KF, Sortenberg W, Nornes H: Cerebrovascular autoregulation dynamics in humans. Stroke 20: 45-52,1989

2. Akerman S, Goadsby PJ: Topiramate inhibits cortical spreading depression in rat and cat: Impact in migraine aura. Neuroreport 16:1383-1387,2005

3. Akerman S, Goadsby PJ: Topiramate inhibits trigeminovascular activation: An intravital microscopic study. Br J Pharmacol 146:7-14,2005

4. Akerman S, Williamson DJ, Kaube H: Nitric oxide synthase inhibitors can antagonize neurogenic and calcitonin generelated peptide induced dilation of dural meningeal vessels. Br J Pharmacol 137:62-68,2002

5. Alemdar M, Selekler HM, Komsuoğlu SS: Temporal characteristics of migraine-type headache. Agri 21(4):168-174,2009

6. Ayata C, Jin H, Kudo C, Dalkara T, Moskowitz MA: Suppression of cortical spreading depression in migraine prophylaxis. Ann Neurol 59(4):652-661,2006

7. Claassen J, Zhang R, Fu Q, Witkowski S, Levine B: Transcranial Doppler estimation of cerebral blood flow and cerebrovascular conductance during modified rebreathing. J Appl Physiol 102:870-877,2007
8. Dahl A, Russell D, Rootwelt K, Nyberg-Hansen R, Kerty E: Cerebral vasoreactivity assessed with transcranial doppler and regional cerebral blood flow measurements. Stroke 26: 2302-2306,1995

9. Dora B, Balkan S: Exaggerated interictal cerebrovascular reactivity but normal blood flow velocities in migraine without aura. Cephalalgia 22(4):288-290,2002

10. Dora B, Balkan S, Tercan E: Normalization of high interictal cerebrovascular reactivity in migraine without aura by treatment with flunarizine. Headache 43(5):464-469,2003

11. Ferrari MD: Migraine. Lancet 351:1043-1051,1998

12. Fiermonte G, Annulli A, Pierelli F: Transcranial Doppler evaluation of cerebral hemodynamics in migraineurs during prophylactic treatment with flunarizine. Cephalalgia 5: 492-496,1999

13. Fiermonte G, Pierelli F, Pauri F, Cosentino F I I, Soccorsi R, Giacomini P: Cerebrovascular $\mathrm{CO} 2$ reactivity in migraine with aura and without aura. A transcranial doppler study. Acta Neurologica Scandinavica 92:166-169,1995

14. Frediani F, Villani V, Cassucci G: Peripheral mechanism of action of antimigraine prophylactic drugs. Neurol Sci 29: 127-130,2008

15. Kastrup A, Thomas C, Hartmann C, Schabet M: Cerebral blood flow and $\mathrm{CO} 2$ reactivity in interictal migraineurs: $A$ transcranial doppler study. Headache 38:608-613,1998

16. Kastrup A, Thomas C, Hartmann C, Schabet M: No effect of prophylactic treatment with metoprolol on cerebrovascular CO2 reactivity in migraineurs. Cephalalgia 6:353-357,1998

17. Kececi H, Atakay S: Effects of topiramate on neurophysiological and neuropsychological tests in migraine patients. Journal of Clinical Neuroscience 16:1588-1591,2009

18. Lauritzen M: Cortical spreading depression in migraine. Cephalalgia 21:757-760,2001

19. Müller M, Voges M, Piepgras U, Schimrigk K: Assessment of cerebral vasomotor reactivity by transcranial Doppler ultrasound and breath-holding. A comparison with acetazolamide as vasodilatory stimulus. Stroke 26:96-100,1995

20. Nedeltchev K, Arnold M, Schwermann M, Nirkko A, Lagger F, Mattle HP, Sturzenegger M: Cerebrovascular response to repetitive visual stimulation in interictal migraine with aura. Cephalalgia 24:700-706,2004

21. Ruiz L, Ferrandi D: Topiramate in migraine progression. J Headache Pain 10:419-422,2009

22. Shank RP, Maryanoff BE: Molecular pharmacodynamics, clinical therapeutics and pharmacokinetics of topiramate. CNS Neurosci Ther 14:120-142,2008

23. Silvestrini $M$, Baruffaldi R, Bartolini M, Vernieri F, Lanciotti $C$, Matteis M, Troisi E, Provinciali L: Basilar and middle cerebral artery reactivity in patients with migraine. Headache 44(1): 29-34,2004

24. Sortenberg W: Cerebral artery blood velocity and cerebral blood flow. In: Newell DW, Aaslid R, (eds), Transcranial Doppler. New York: Raven Press Publishers, 1992:57-66 
25. Storer RJ, Goadsby PJ: Topiramate inhibits trigeminovascular neurons in the cat. Cephalalgia 24:1049-1056,2004

26. Thie A, Fuhlendorf A, Spitzer K, Kunze K: Transcranial Doppler evaluation of common and classic migraine. Part I. Ultrasonic features during the headache-free period. Headache 30(4):201-208,1990

27. Totaro R, Marini C, De Matteis G, Di Napoli M, Carolei A: Cerebrovascular reactivity in migraine during headache-free intervals. Cephalalgia 17(3):191-194,1997

28. Wei EP, Moskowitz MA, Boccalini P: Calcitonin gene-related peptide mediates nitroglycerin and sodium nitroprussideinduced vasodilatation in feline cerebral arterioles. Circ Res 70:1313-1319,1992
29. Wolf $M E$, Jager $T$, Bazner $H$, Hennerici $M$ : Changes in vasomotor reactivity in migraine with aura. Cephalalgia 29:1156-1164,2009

30. Valikovitcs A, Olah L, Fulesdi B, Kaposzta Z, Fincere A, Bereczki D, Csiba L: Cerebrovascular reactivity measured by transcranial Doppler in migraine. Headache 36:323-328,1996

31. Vernieri F, Tibuzzi F, Pasqualetti P, Altamura C, Palazzo P, Rossini $\mathrm{PM}$, Silvestrini $\mathrm{M}$ : Increased cerebral vasomotor reactivity in migraine with aura: An autoregulation disorder? A transcranial Doppler and near-infrared spectroscopy study. Cephalalgia 28:689-695,2008 